Article

\title{
The Environmental, Social, Governance, and Financial Performance Effects on Companies that Adopt the United Nations Global Compact
}

\section{Eduardo Ortas ${ }^{1, *}$, Igor Álvarez ${ }^{2}$ and Ainhoa Garayar ${ }^{2}$}

1 Accounting and Finance Department, Faculty of Economics and Business Administration, University of Zaragoza, $C \backslash$ Gran Vía n²2, 50005 Zaragoza, Spain

2 Financial Economics Department, Faculty of Economics and Business Administration, University of Basque Country, C $\backslash$ Oñati $n^{\circ} 1$, 20018 San Sebastián, Spain;

E-Mails: igor.alvarez@ehu.es (I.Á.); ainhoa.garayar@ehu.es (A.G.)

* Author to whom correspondence should be addressed; E-Mail: edortas@unizar.es; Tel.: +34-976-761-000 (ext. 4915); Fax: +34-974-042-054.

Academic Editor: Rachel J. C. Chen

Received: 22 December 2014 / Accepted: 6 February 2015/ Published: 11 February 2015

\begin{abstract}
This paper aims to investigate companies' environmental, social, governance (ESG), and financial implications of their commitment to the United Nations Global Compact (UNGC). The focus is placed on companies operating in the three countries with the highest number of UNGC participants: Spain, France, and Japan. The results clearly reveal that adoption of the UNGC often requires an organizational change that fosters stakeholder engagement, ultimately resulting in improvements in companies' ESG performance. Additionally, the results reveal that ESG performance has a significant impact on financial performance for companies that adopted the principles of the UNGC. These findings provide both non-financial and financial incentives to companies to commit to this voluntary corporate social responsibility (CSR) initiative, which will have important implications on companies' strategic management policies that aim to foster sustainable businesses and community development. Finally, the linkages between the UNGC-committed companies' ESG and financial performance may be influenced by geographical spread, mainly due to the appearance of differences in the institutional, societal, and cultural settings.
\end{abstract}

Keywords: United Nations Global Compact; environmental performance; social performance; stakeholders; sustainable development; stakeholder theory 


\section{Introduction}

During the last 20 years, several corporate social responsibility (CSR) voluntary initiatives have emerged asking corporations to adhere to a predefined set of norms and values [1]. Examples of these initiatives are the Global Reporting Initiative (GRI) [2], Social Accountability 8000 [3], and the ISO 14000 [4]. Among this catalog of voluntary CSR initiatives, the United Nations Global Compact (hereafter, the UNGC) is one of the most prominent and widespread CSR initiatives implemented by companies around the world [5,6]. As of December 2014, more than 12,700 business and non-business participants are part of the initiative. The underlying idea of the UNGC is that business participants advance broader UN objectives as well as 10 specific principles in the following four areas: (1) human rights, (2) labor rights, (3) the environment, and (4) anticorruption [1]. The UNGC is designed to be an expression of obligations and responsibilities taken by organizations implemented in response to external institutional pressures and constraints. The main advantage of the UNGC - like that of other CSR initiatives - is that it has the ability to promote social responsibility by serving as a guide toward greater transparency and accountability [7]. Moreover, the UNGC encouraged the dialogue between several social actors who had never previously engaged in discussion [7]. Another interesting feature of the UNGC is the social network resulting from interaction among participants [8]. Due to the growing relevance of such voluntary CSR initiatives, a large amount academic research has focused on analyzing the historical and political context of the UNGC $[9,10]$, discussing the role of the UNGC in global governance [10], identifying the underlying organizations' motivations to adopt the UNGC [11], and identifying the specific financial and non-financial profiles of the UNGC participants.

Despite the rapid growth in the number of academic works in this field [12], the corporate ESG and financial implications of the implementation of the UNGC remain under-investigated $[1,13,14]$. To address this issue, this work aims to investigate whether the firms' commitment to the UNGC has an influence on companies' ESG and financial performances. To this end, the ESG performance of companies in the three countries with the highest rate of UNGC adoption — Japan, France, and Spain —is examined. One distinct feature of this paper is companies' ESG performance being assessed into three “dimensions" [15]: corporate social (CSP), environmental (CEP), and governance performance (CSP). Based on that sample, this work also contributes to previous literature by investigating the possible appearance of bidirectional linkages between companies' ESG performance and financial performance (CFP). Finally, we test for a country's moderating effect in order to capture whether the geographical context in which the companies develop their businesses significantly modifies the aforementioned relationships. All of these analyses will reveal fresh and interesting insights that have been scarcely analyzed in previous research in the field. In fact, the results clearly reveal that companies' commitment to the UNGC has a positive impact on ESG performance. This finding is of special importance for companies' strategic management, as it provides non-financial incentives to adopt the UNGC, thus enhancing environmental preservation, human well-being, social justice, and sustainable community development. Moreover, several positive bidirectional links exist between ESG performance and CFP in companies that adopted the UNGC. This finding is also interesting because, in the absence of non-financial incentives to adopt the UNGC, the financial incentives can encourage UNGC adoption, which will ultimately result in collaborative solutions to broadly accepted societal and environmental objectives. Finally, some positive moderating effects appear in the companies' ESG 
and financial performance linkages, clearly indicating that the geographical spread of businesses play a significant role in the aforementioned relationships, an issue that has not been addressed by previous research.

The remainder of this paper proceeds as follows: The second section provides a brief introduction to the objectives, main features of the UNGC; reviews the previous research in the field; and motivates the research hypotheses. The third section describes the sample and the measures of firms' ESG and financial performances and introduces the main econometric models applied in the empirical section. Section 4 discusses the main results of the research. Finally, the conclusions and implications of the research are provided in the last section.

\section{Global Compact Features, Literature Review, and Hypotheses}

\subsection{The UNGC and Its Impact on Companies' ESG Performance}

The UNGC, first presented at the 1999 World Economic Forum in Davos by Secretary-General Kofi Annan and launched in July 2000, is an extensive network that encompasses different participants, such as companies, trade unions, social organizations-foundations and non-governmental organizations (NGOs) - and governments. As of December 2014, the UNGC had more than 12,700 signatories. Articulated around 10 principles relating to human rights, labor rights, the environment and anticorruption, the UNGC requires support, collaboration, and commitment to implement these principles in each of the areas that a company can influence. The 10 principles were selected according to their relevance to international rule-making, their importance in advancing social and environmental issues, and the extent to which they had inter-governmental support [16]. Specifically, they were derived from the Universal Declaration of Human Rights (UDHR), the International Labour Organization (ILO) Declaration on Fundamental Principles and Rights at Work, and the Rio Declaration on Environment and Development. The UNGC is conceived as a learning network rather than a compliance-based standard or model [17], which focuses on "the dissemination of practical know-how and tools on CSR" [18].

The growing relevance both at the institutional and organizational levels of the UNGC has attained the interest of academics, resulting in an emerging body of research that can be classified into three different perspectives: (1) research discussing the UNGC in the context of UN-business relations; (2) research discussing the UNGC in the context of the changing dynamics of multi-actor and multi-level global governance; and (3) research on the operational dimension of the UNGC [1].

The works classified under the first research perspective have mainly focused on investigating the historical and political context of the UNGC $[9,10]$. These works generally concluded that the UNGC has shifted the relationship between the UN and the private sector in two interrelated ways: First, the UNGC shifted the UN's traditional perspective of focusing on the impacts of transnational companies from a belief in solutions focused on interstate negotiations toward a more widespread and voluntary multi-actor model that incorporates companies as well as state actors. Second, the adoption of a more inclusive model also modified the very nature of UN-business relationships from a largely reactive to a more proactive attitude [1]. 
The works classified under the second perspective (i.e., governance perspective) follow a macro-level approach discussing the UNGC's role in global governance. Specifically, works in this perspective conceive the UNGC as an expression of a novel global public domain [10], thus noting some opportunities and constraints that influence the way the global governance is implemented. The works that have adopted this perspective have mostly focused on the institutional design of the UNGC and how it contributes to implementing governance in the new public domain. For example, Ruggie [19] indicates that the multi-actor design of the UNGC and its emphasis on dialogue and learning can enhance the legitimacy of governance solutions. Conversely, Soederberg [20] criticizes the design of the UNGC and argues that the UNGC does not empower civil society actors and thus remains exclusionary.

The works classified under the third perspective focus on three key areas: (1) the firms' motivations to adopt the UNGC; (2) the composition of the UNGC participants; and (3) the impact of committed firms' operations and business strategies. Regarding the latter, several works have focused on analyzing the financial and non-financial benefits of the UNGC adoption, such as improvements in corporate image, the option of making the organization stand out from the competition, learning better practices, obtaining competitive advantages, and facilitating strategic changes when implementing the principles [11]. However, these studies paint a mixed picture of the UNGC's impact on business practices [21] mainly due to the following reasons: (1) the different stages of business performance of the participating firms [22] and (2) the heterogeneous nature of participating firms' size, geographical spread, and industry sector. Moreover, only a few studies - under this third perspective-have investigated whether the firms' commitment to the UNGC impacts their CEP, CSP, and CGP levels. However, the UNGC 2012 survey supports the idea that the majority of committed companies are putting policies in place, as well as related actions to preserve the environment and to improve labor standards at the highest rates though anticorruption efforts [23].

The above-mentioned literature mainly provided a practitioner-oriented overview of attitudes toward sustainability under the scope of the UNGC. As a result, little is known about the ESG implications of the adoption of the UNGC. To address this issue, this paper aims to test whether the commitment to the UNGC influences companies' ESG performance, an issue that, to the best of the authors' knowledge, remains unclear. We focus on three countries (i.e., Spain, France, and Japan) with contrasted differences in their cultural and institutional settings. Furthermore, according to data published by the United Nations Global Compact Office (UNGCO), Spain, France, and Japan are the countries with the highest rate of participating organizations. Spain has led the field since 2009 and represents $14 \%$ of the total, while France represents $8 \%$ and Japan $2 \%$. Thus, this analysis acquires more representativeness. Based on this selection, the results will not be biased because, such as indicated by Harms et al. [24], it could be expected that the degree of implementation of the 10 principles of the UNGC varies according to country-specific historical and cultural backgrounds, as well as the resulting ESG conditions. For example, previous research indicates that: (1) environmental aspects are the main sustainability issues for Spanish companies due to the impact of environmental disasters on Spanish society over the last several decades [25]; (2) environmental issues are less managed in French companies, in line with stakeholders' demands, mainly because stakeholders would like stricter management of social issues showing high values for the issues of training and development, diversity and equal opportunity, and consumer protection [26]; and (3) Japanese 
companies manage biodiversity closely, a topic that receives considerably less international attention on average [27]. Based on these premises, the following hypothesis will be tested:

H1: Corporate commitment to the UNGC has a positive influence on firms' ESG performance.

The non-rejection of this hypothesis may be motivated by the fact that companies that adopt the UNGC often experience a positive organizational change resulting from stakeholders' engagement, which fosters the UDHR, sustainable development, and the common good.

\subsection{Bidirectional Linkages between ESG and Financial Performances of Companies Committed to the UNGC}

The instrumental approach of CSR [28,29] has widely investigated the link between firms' ESG and financial performances [30,31]. Given the inherent instrumentality of sustainable development [32], it is often argued that companies will only contribute to sustainable development if they perceive an incentive to do so [33]. An environmentally friendly company that is not economically friendly will sooner or later disappear from the market, along with its environmentally beneficial activities [34]. This consideration is similar to the business-case model of CSR defined by Berger et al. [35], which considers CSR initiatives as adopted for purely rational and economic reasons for years; thus, the link between a good social/environmental performer and a good financial performer has been a core topic in corporate social/environmental management.

Instrumental Stakeholder Theory [36,37] suggests a positive relationship between companies' ESG and financial performances [31,38-43]. However, the literature has also established the importance of the direction $[15,29,33,44]$. That is, do improvements in companies' ESG performance generate improved levels of CFP? Or do improvements in CFP generate improved levels of firms' ESG performance? Thus, two views can be justified theoretically and tested empirically: slack resources and good management theories [15].

Slack resources theory argues that better CFP potentially results in the availability of slack financial and other resources that provide the opportunity to invest in ESG activities [15]; thus, better CFP would be a predictor of better corporations' ESG performance [45]. This is in line with the view that financially successful companies have more financial resources that they can spend on ESG issues and therefore attain a higher performance $[15,30,31,33,44,46]$. This view is often based on the belief that good ESG performance is a type of luxury good for a company after it has reached high economic success [34]. The most successful companies have the most financial resources and can spend the most on CSR activities [15,44,46]. Seifert et al. [47] suggest that a company's free cash flows - one of the most discretionary types of organizational slack - has a significant impact on its cash donations to charitable causes. However, if companies have fewer financial resources and consider ESG issues unnecessary, they would of course reduce the funding for CSR activities, and therefore their ESG performance could deteriorate [33]. Based on these premises, the following hypothesis is proposed:

H2: Corporate financial performance has a positive impact on ESG performance for companies committed to the UNGC.

Good management theorists argue that there is a positive correlation between the implementation of good management practices and CFP [15] because attention to CSR improves the stakeholders' 
engagement [48], resulting in financial success [45]. Companies' ESG performance as a distinctive resource may generate benefits or reduce costs, both of which improve CFP [30] - for example, reducing costs by mitigating the likelihood of negative regulatory, or legislative, actions $[39,48]$ or reducing cost in the production process. Christmann [49], who assessed survey data from 88 chemical companies, found that capabilities for process innovation and implementation are complementary assets that moderate the relationship between environmentally friendly best practices and cost advantage, which are significant factors in determining CFP. Ruf et al. [50] revealed that changes in firms' ESG performance were positively associated with growth in companies' sales for the current and subsequent years. In accordance with these arguments, good management theory suggests that the appearance of doing well (or the perception among key stakeholders that a company is doing well) generates demand for and commitment to the company's stock, jobs, or products [30]. This can be explained by the fact that the cost of having a high level of ESG performance is minimal and that firms may actually benefit from socially responsible actions in terms of employee morale and productivity [51]. In this vein, Choi and $\mathrm{Yu}$ [52] concluded that perceptions of CSR practices have a positive impact on their organizational commitment and organizational citizenship behavior, and this behavior partially mediates the relationship between CSR practices and CFP. Firms can be more successful by developing (up to some margin) relationships with customers, employees, communities, and governments $[53,54]$, differentiating the firm's products/services and thereby attracting socially responsive investors [55]. Ribstein [56] considered that CSR could determine higher financial results based on the improvement of strategy processes and also on employee, customer, and society loyalty. Peloza [57] shows that positive CSR acts as insurance by protecting reputation and reducing the financial impact of negative publicity. Pan et al. [58] found that shareholder responsibility; employee responsibility; environmental responsibility; and supplier, customer, and consumer responsibility have significant relationships with CFP. Moreover, the perception of being an "ethical" company could improve the company's reputation [59], which is a key factor for its success or for attracting financial resources from socially responsible investors. Based on these premises, the following hypothesis is proposed:

H3: Companies' ESG performance has a positive impact on financial success for UNGC-committed firms.

\subsection{The Role of Country as a Moderator Variable}

Previous research has demonstrated that managers behave differently across countries because they are highly influenced by the national cultural values [60-63], organizational culture [64,65], or businesses in which they are embedded [66]. In that context, several studies have been developed with the aim of showing those differences in firms' CSR priorities depending on the home country of the companies. Specifically, Welford [67] studied companies from the U.K., Norway, Hong Kong, and Singapore, concluding that companies respond to what is important in their own country. Maignan and Ralston [68] found that continental European companies show lower levels of emphasis on codes of ethics and philanthropic CSR than those in the U.S., while the U.S. companies do not show higher levels of environmental performance. Baughn et al. [69] compared two themes of CSR-environmental and social issues - in 14 Asian countries with companies from Western Europe, Australia, New Zealand, 
U.S., Canada, the Middle East, and Africa. They reveal strong relationships between CSR and ESG practices and the country's economic, political, and social contexts, which reflect the importance of a country's development of such institutional capacity to promote and support CSR practices. Aaronson et al. [70] analyzed the differences between U.K. and U.S. firms. They conclude that firms in U.K and the U.S. - two nations with similar political and entrepreneurial cultures - have taken such different approaches to CSR policies. Thus, it is reasonable to think that firms' CSR and ESG activities may be valued differently by shareholders on the one hand and, on the other hand, by other stakeholders in different countries with different cultural and institutional backgrounds [71]. Given this factor, the present work considers companies operating in three countries with different institutional characteristics [72] and legal and judicial traditions [71]. The following hypothesis is proposed and will be tested:

H4: The links between ESG performance and financial performance of firms is moderated by their geographical spread.

The non-rejection of this hypothesis will inform us that the financial benefits derived from improvements in firms' ESG performance may differ from country to country. In fact, CFP may affect ESG efforts differently from country to country, as financial objectives and respective CSR objectives (social, environmental, and corporate governance) may differ according to the country.

\section{Sample, Data, and Method}

This research focuses on companies operating in the three countries that the highest rate of firms committed to the UNGC: Spain, France, and Japan. The data used in this work is twofold: (1) data related to firms' ESG performance, and (2) data related to the market and accounting proxies of CFP. Companies' ESG performance was measured by examining the corporate environmental (CEP), social (CSP), and governance performance (CGP) composite ESG indexes provided by the ASSET4 ${ }^{\circledR}$ database of DataStream provided by Thomson Reuters Inc., which provides objective and systematic ESG data using more than 280 key performance indicators and 750 individual data points and their original data sources from over 4000 global companies, including MSCI World, MSCI Europe, STOXX 600, NASDAQ 100, ASX 300, and MSCI Emerging Markets. The companies' ESG performance measures comprise variables that capture a wide range of stakeholder performance issues, assessed by independent external social audits [31] that apply social and environmental screens, thus reflecting companies' social, environmental, and corporate governance strengths and weaknesses. This dataset, such as that provided by the Kinder, Lydenberg, and Domini (KLD) dataset, is recognized as the most complete rating of ESG performance and social responsibility. The database search provided a total of 198 companies operating in Spain, France, and Japan that are committed to the UNGC. These companies were monitored from 2008-2013, grouped in 10 primary economic sectors in the Global Industry Classification Standard (GICS) system. Firms' CSP, CEP, and CGP measures are defined as follows:

- CSP: measures a company's capacity to generate trust and loyalty in its workforce, customers, and society, through its use of best management practices. It is a reflection of the company's reputation, which is a key factor in determining its ability to generate long-term value. This 
composite index results from a weighted score of the company's strengths and weakness on indicators related to: (a) product responsibility, (b) community, (c) human rights, (d) diversity and opportunity, (e) employment quality, (f) health and safety and (g) training and development.

- CEP: measures a company's impact on living and non-living natural systems, including the air, land, and water, as well as complete ecosystems. It reflects the extent to which a company uses best management practices to avoid environmental risks and capitalize on environmental opportunities. This composite index results from a weighted score of the company's strengths and weaknesses on indicators related to: (a) emission reduction, (b) product innovation, and (c) resource consumption reduction.

- CGP: measures a company's systems and processes, which ensure that its board members and executives act in the best interests of its long-term shareholders. It reflects a company's capacity, through its use of best management practices, to direct and control its rights and responsibilities through the creation of incentives. This composite index results from a weighted score of the company's strengths and weaknesses on indicators related to: (a) board functions, (b) board structure, (c) compensation policy, (d) vision and strategy, and (e) shareholder rights.

These composite indexes take values from 0-100. The higher the company's score on each composite index, the higher their level of CSP, CEP, or CGP.

CFP has been measured through both accounting and market based proxies drawn from the DataStream database: (1) companies' Tobin's q (TQ) and (2) companies' return on assets (ROA). Whereas ROA is defined as a company's profits before taxes divided by the average of its total assets, the TQ is the ratio of the firm market value to the replacement cost of its assets. TQ has been measured in this paper following the simple approximation of Lindenberg and Ross [73], as provided by Lee and Tompkins [74]. Market-based and accounting-based methods for measuring CFP each have their advantages and limitations. On the one hand, accounting-based measures focus on firms' historical assessment of accounting profitability, capturing indicators such as ROA, assets growth, operating revenue, etc., which can be biased due to the differences in accounting procedures and managerial manipulation. On the other hand, market-based measures are less susceptible to accounting rules and managerial manipulation, but are only related to the shareholders instead of focusing on firms' stakeholders. However, the consideration of both types of CFP measures may provide a more comprehensible picture of the hypothesized relationships.

Finally, we included several control variables: (1) firms' size (SIZE), measured by the natural logarithm of the companies' total assets. This transformation is made because the distribution of firms' total assets is commonly non-normally distributed. This control variable should be especially relevant because of the possible appearance of scale economies related to environmentally and socially oriented investments and initiatives; (2) companies' leverage (LEV), a proxy of firms' risk defined as the ratio of the total debt to total assets; (3) the economic sector in which the different companies operate (i.e., basic materials, consumer cyclicals, consumer non-cyclicals, energy, financials, healthcare, industrials, technology, telecommunication services, and utilities); and (4) research and development (R\&D) intensity measured by the ratio of the $R \& D$ expenditure to total sales. This control variable has been considered since omitting it from models of the relationship between CSP, CEP, and CFP will likely lead to misleading results [75]. This is because the process of product differentiation may include 
investment in R\&D projects intended to add social and environmental attributes to the product that are acknowledged by customers [76]. Finally, we control for time-specific factors.

To test for the hypothesized relationships, several time-random effects panel data models have been estimated considering the degree of CEP, CSP, and CFP as dependent variables. The baseline models for the $\mathbf{H 1}$ hypothesis are given by:

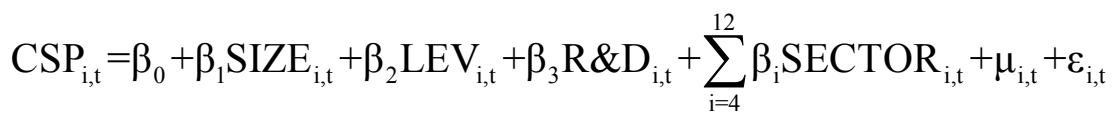

$$
\begin{aligned}
& \mathrm{CEP}_{\mathrm{i}, \mathrm{t}}=\beta_{0}+\beta_{1} \mathrm{SIZE}_{\mathrm{i}, \mathrm{t}}+\beta_{2} \mathrm{LEV}_{\mathrm{i}, \mathrm{t}}+\beta_{3} \mathrm{R}_{\mathrm{i}} \mathrm{D}_{\mathrm{i}, \mathrm{t}}+\sum_{\mathrm{i}=4}^{12} \beta_{\mathrm{i}} \mathrm{SECTOR}_{\mathrm{i}, \mathrm{t}}+\mu_{\mathrm{i}, \mathrm{t}}+\varepsilon_{\mathrm{i}, \mathrm{t}} \\
& \mathrm{CGP}_{\mathrm{i}, \mathrm{t}}=\beta_{0}+\beta_{1} \mathrm{SIZE}_{\mathrm{i}, \mathrm{t}}+\beta_{2} \mathrm{LEV}_{\mathrm{i}, \mathrm{t}}+\beta_{3} \mathrm{R}_{\mathrm{i}} \mathrm{D}_{\mathrm{i}, \mathrm{t}}+\sum_{\mathrm{i}=4}^{12} \beta_{\mathrm{i}} \mathrm{SECTOR}_{\mathrm{i}, \mathrm{t}}+\mu_{\mathrm{i}, \mathrm{t}}+\varepsilon_{\mathrm{i}, \mathrm{t}}
\end{aligned}
$$

where CSP, CEP, CGP, SIZE, LEV, and R\&D intensity have been previously defined; and SECTOR is different dummy variables that take the value of 1 if the company "i" operates in sector " $\mathrm{j}$ " (basic materials is the baseline case for sector dummies). In order to test whether the commitment to the UNGC influences the companies' degree of ESG performance, the initial dataset has been broadened to include other companies that do not adhere to the UNGC. With the aim of obtaining a homogeneous augmented sample, the additional companies have been selected through a matching approach that considers the following parameters of firms: country, economic sector, firm size, firm total assets, and sales and leverage. The augmented sample consists of 396 companies (i.e., 198 firms committed to the UNGC and 198 that are not committed to that initiative). On the augmented sample, the following restricted panels have been estimated:

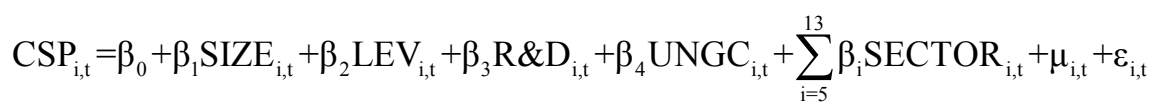

$$
\begin{aligned}
& \operatorname{CSP}_{i, t}=\beta_{0}+\beta_{1} \operatorname{SIZE}_{i, t}+\beta_{2} \operatorname{LEV}_{i, t}+\beta_{3} \operatorname{RED}_{\mathrm{i}, \mathrm{t}}+\beta_{4} \mathrm{UNGC}_{\mathrm{i}, \mathrm{t}}+\sum_{\mathrm{i}=5}^{13} \beta_{\mathrm{i}} \operatorname{SECTOR}_{\mathrm{i}, \mathrm{t}}+\mu_{\mathrm{i}, \mathrm{t}}+\varepsilon_{\mathrm{i}, \mathrm{t}} \\
& \operatorname{CGP}_{i, t}=\beta_{0}+\beta_{1} \operatorname{SIZE}_{i, t}+\beta_{2} \operatorname{LEV}_{i, t}+\beta_{3} \operatorname{R}_{i, t}+\beta_{4} \mathrm{UNGC}_{i, t}+\sum_{\mathrm{i}=5}^{13} \beta_{\mathrm{i}} \operatorname{SECTOR}_{\mathrm{i}, \mathrm{t}}+\mu_{\mathrm{i}, \mathrm{t}}+\varepsilon_{\mathrm{i}, \mathrm{t}}
\end{aligned}
$$

where UNGC is a dummy variable that takes a value equal to 1 if the company "i" is committed to the UNGC and zero otherwise; the rest of the variables are previously defined. These models have been estimated with consideration given to the independents in levels and lagged one period to test for robustness in the estimates. The acceptance/rejection of the $\mathbf{H 1}$ hypothesis will be discussed by examining the significance of the parameters associated with the UNGC parameters.

Related to the $\mathbf{H} \mathbf{2}$ hypothesis, which aimed to test whether, in the firms committed to the UNGC, a relationship existed between the firms' level of CFP and their ESG success, the following set of panels have been estimated:

$$
\begin{aligned}
& \operatorname{CSP}_{\mathrm{i}, \mathrm{t}}=\beta_{0}+\beta_{1} \mathrm{ROA}_{\mathrm{i}, \mathrm{t}-1}+\beta_{2} \mathrm{TQ}_{\mathrm{i}, \mathrm{t}-1}+\sum_{\mathrm{i}=3}^{5} \beta_{\mathrm{i}} \mathrm{FCs}_{\mathrm{i}, \mathrm{t}-1}+\sum_{\mathrm{i}=6}^{14} \beta_{\mathrm{i}} \operatorname{SECTOR}_{\mathrm{i}, \mathrm{t}}+\mu_{\mathrm{i}, \mathrm{t}}+\varepsilon_{\mathrm{i}, \mathrm{t}} \\
& \mathrm{CEP}_{\mathrm{i}, \mathrm{t}}=\beta_{0}+\beta_{1} \mathrm{ROA}_{\mathrm{i},-\mathrm{t}-1}+\beta_{2} \mathrm{TQ}_{\mathrm{i}, \mathrm{t}-1}+\sum_{\mathrm{i}=3}^{5} \beta_{\mathrm{i}} \mathrm{FCs}_{\mathrm{i}, \mathrm{t}-\mathrm{1}}+\sum_{\mathrm{i}=6}^{14} \beta_{\mathrm{i}} \operatorname{SECTOR}_{\mathrm{i}, \mathrm{t}}+\mu_{\mathrm{i}, \mathrm{t}}+\varepsilon_{\mathrm{i}, \mathrm{t}}
\end{aligned}
$$




$$
\mathrm{CGP}_{\mathrm{i}, \mathrm{t}}=\beta_{0}+\beta_{1} \mathrm{ROA}_{\mathrm{i},-\mathrm{-}-1}+\beta_{2} \mathrm{TQ}_{\mathrm{i},-1-1}+\sum_{\mathrm{i}=3}^{5} \beta_{\mathrm{i}} \mathrm{FCs}_{\mathrm{i}, \mathrm{t}-1}+\sum_{\mathrm{i}=6}^{14} \beta_{\mathrm{i}} \mathrm{SECTOR}_{\mathrm{i}, \mathrm{t}}+\mu_{\mathrm{i}, \mathrm{t}}+\varepsilon_{\mathrm{i}, \mathrm{t}}
$$

where CSP, CEP, and CGP are the degree of social, environmental, and governance performance of the company "i"; FCs refer to the financial control variables previously introduced (i.e., size, leverage, and R\&D intensity); the rest of the parameters were previously defined. Due to the scarce differences observed when estimating the previous models in terms of levels and considering the first lag of the independent variables, we selected the latter approach because it is more consistent with the idea that the effects of companies' financial performance on their ESG performance are likely to be observed in subsequent periods. The acceptance/rejection of the $\mathbf{H 2}$ hypothesis will be discussed by examining the significance of the parameters associated with ROA and TQ variables.

Regarding the $\mathbf{H 3}$ hypothesis, which aimed to examine whether, in the firms committed to the UNGC, a relationship existed between the firms' ESG performance and their CFP, the following set of panels have been estimated:

$$
\begin{aligned}
& \mathrm{TQ}_{\mathrm{i}, \mathrm{t}}=\beta_{0}+\beta_{1} \mathrm{CSP}_{\mathrm{i}, \mathrm{t}-1}+\beta_{2} \mathrm{CEP}_{\mathrm{i}, \mathrm{t}-1}+\beta_{3} \mathrm{CGP}_{\mathrm{i}, \mathrm{t}-1}+\sum_{\mathrm{i}=4}^{6} \beta_{\mathrm{i}} \mathrm{FCs}_{\mathrm{i}, \mathrm{t}-1}++\sum_{\mathrm{i}=7}^{15} \beta_{\mathrm{i}} \mathrm{SECTOR}_{\mathrm{i}, \mathrm{t}}+\mu_{\mathrm{i}, \mathrm{t}}+\varepsilon_{\mathrm{i}, \mathrm{t}} \\
& \operatorname{ROA}_{i, t}=\beta_{0}+\beta_{1} \operatorname{CSP}_{i, t-1}+\beta_{2} \operatorname{CEP}_{i, t-1}+\beta_{3} \operatorname{CGP}_{i, t-1}+\sum_{i=4}^{6} \beta_{i} \operatorname{FCs}_{i, t-1}+\sum_{i=7}^{15} \beta_{i} \operatorname{SECTOR}_{i, t}+\mu_{i, t}+\varepsilon_{i, t}
\end{aligned}
$$

where all of the variables have been previously defined. The acceptance/rejection of the $\mathbf{H 3}$ hypothesis will be discussed by examining the significance of the parameters associated with CSP, CEP and CGP variables.

Regarding the $\mathbf{H 4}$ hypothesis, as indicated in Figure 1, it was tested whether the country in which the companies operate moderates the relationship between the firms' ESG performance and CFP. To do this, panels (7) to (11) have been re-estimated but include all the cross products of the CSP, CEP, CGP, country spread, and both the CFP and country spread as independent variables in each model where a significant effect was found in the initial models (Spain is the baseline case for country dummies).

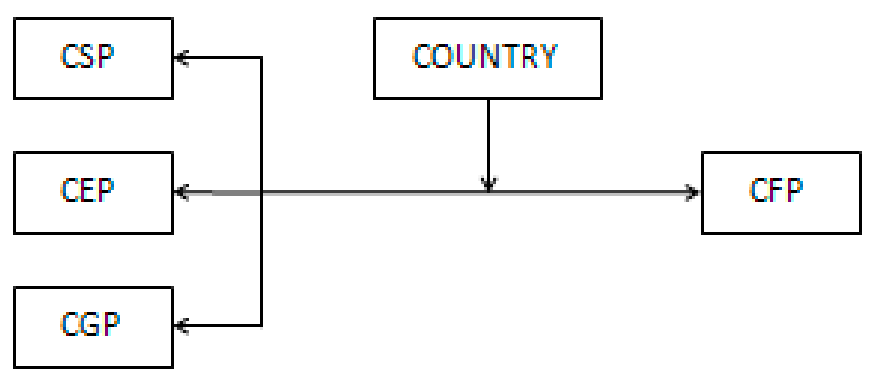

Figure 1. The moderating effect of country on the relationship between Corporate Social (CSP), Environmental (CEP), Governance (CGP), and Financial Performance (CFP).

The acceptance/rejection of the $\mathbf{H 4}$ hypothesis will be discussed by examining the significance of the parameters associated with the cross products of the CSP, CEP, CGP, country and CFP, and the country variables. 


\section{Results and Discussion}

This section reviews the main results provided in the empirical analysis. Table 1 shows the basic descriptive statistics of the variables included in the models and their cross-correlations. A first look at the table reveals that the environmental dimension (i.e., CEP), followed by the social dimension (i.e., CSP), has the highest ESG mean score of the companies examined. On the contrary, the companies' level of CGP seems to be relatively lower than the other two dimensions. Furthermore, the three measures of companies' ESG performance (i.e., CEP, CSP, and CGP) seem to be highly and positively correlated. CEP is positively correlated with the two measures of CFP (i.e., ROA and TQ). However, the rest of the firms' ESG performance measures present scarce correlation with companies' ROA and TQ. As expected, TQ and ROA are positively correlated, an aspect that confirms the idea that a profitable company is usually better valuated by the investors in the stock market. The financial control variables (i.e., size, leverage, and R\&D intensity) appear to be correlated in different ways with companies' CFP and CSP, and their CEP and CGP (e.g., companies' size is positively correlated with CEP and negatively associated with TQ). Finally, the mean score of the companies in the UNGC variable is 0.5 . This is because the augmented sample considers the 198 companies committed to the UNGC and 198 firms that do not comply with the voluntary CSR initiative. 
Table 1. Descriptive statistics and variable pairwise correlations.

\begin{tabular}{|c|c|c|c|c|c|c|c|c|c|c|c|}
\hline & Mean & SD & CEP & CSP & CGP & TQ & ROA & Size & Leverage & $\begin{array}{c}\text { R\&D } \\
\text { intensity }\end{array}$ & UNGC \\
\hline CEP & 66.25 & 31.26 & 1 & & & & & & & & \\
\hline CSP & 56.64 & 33.57 & 0.773 & 1 & & & & & & & \\
\hline CGP & 23.42 & 24.91 & 0.400 & 0.555 & 1 & & & & & & \\
\hline TQ & 1.224 & 0.658 & 0.097 & 0.007 & 0.077 & 1 & & & & & \\
\hline ROA & 2.984 & 5.393 & 0.098 & 0.034 & 0.042 & 0.411 & 1 & & & & \\
\hline Size & 19.61 & 2.309 & 0.086 & -0.017 & -0.433 & -0.311 & -0.132 & 1 & & & \\
\hline Leverage & 1.255 & 1.102 & 0.016 & 0.022 & 0.014 & -0.006 & -0.043 & -0.032 & 1 & & \\
\hline $\mathrm{R} \& \mathrm{D}$ intensity & 3.535 & 3.535 & 0.156 & 0.188 & 0.113 & 0.233 & -0.055 & -0.134 & -0.019 & 1 & \\
\hline UNGC & 0.500 & 0.478 & 0.323 & 0.451 & 0.419 & -0.002 & -0.004 & -0.124 & 0.033 & 0.049 & 1 \\
\hline
\end{tabular}

This table shows the main descriptive statistics of the considered variables and their pairwise correlations. $\mathrm{N}=396$. All correlations above $|.07|$ are significant at the $p=0.05$ level (2-tailed). 
Figure 2 shows several boxplots that refer to the companies' score on the ESG performance measures classified by country and by the companies' commitment to the UNGC. Some interesting features of this figure warrant comment. First, the companies' levels of ESG performance appear to be higher in those companies committed to the UNGC. Second, these differences are more remarkable when examining the firms' CEP and CSP than when analyzing their CGP levels. This could be preliminary evidence of higher performance on environmental, social, and corporate governance dimensions for those companies that consider the principles of the UNGC. However, this issue will be analyzed in detail when examining the results obtained after estimating Equations (1) to (6). Third, the companies' ESG performance seems to be influenced by their geographical spread. This is because, although companies' CEP seems to be homogeneous for the companies committed to the UNGC, the firms' CSP and CGP are higher in Spanish and French than in Japanese companies.

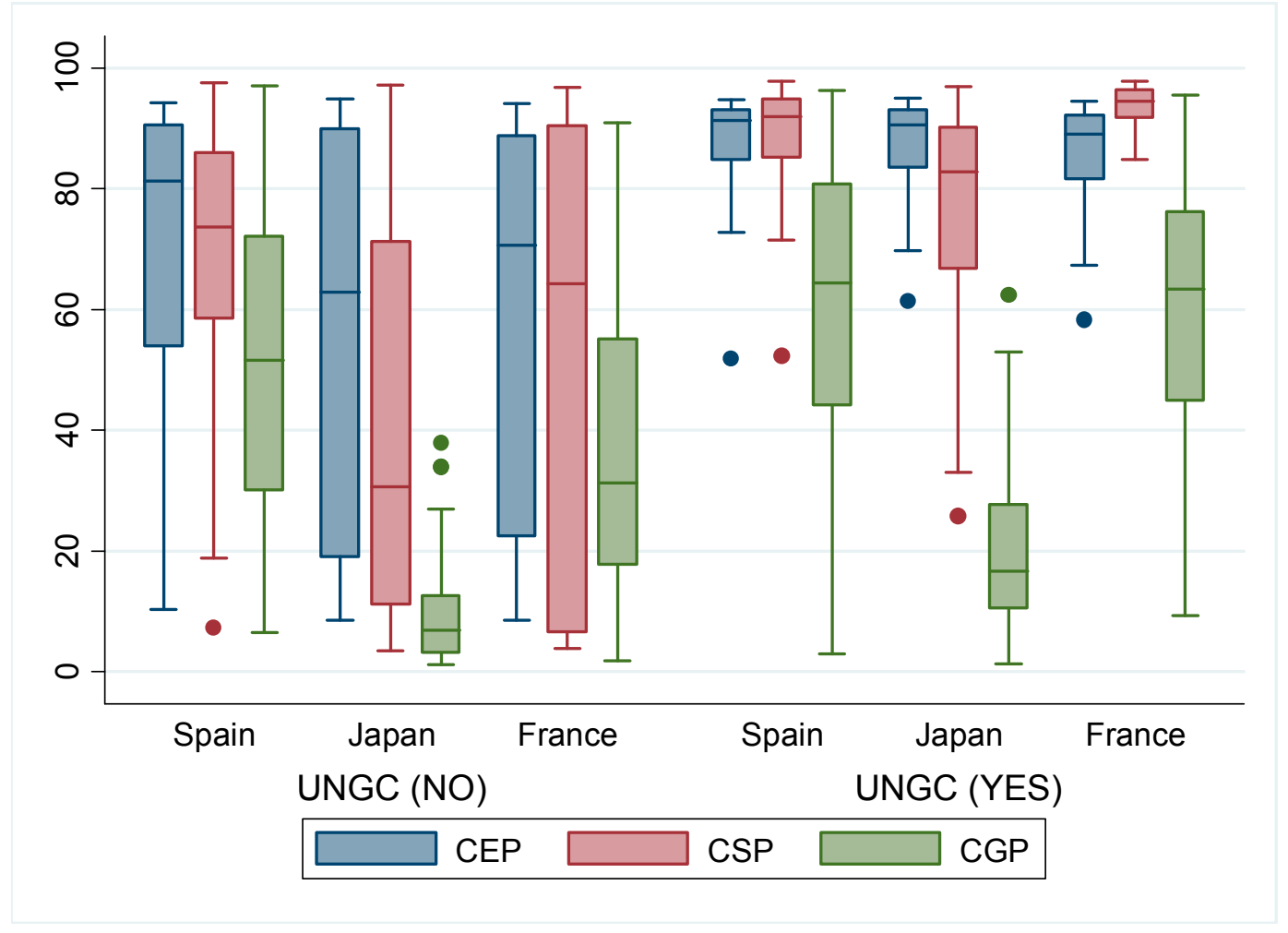

Figure 2. CSP, CEP, and CGP by commitment to UNGC and country.

Table 2 shows the estimates of the Equations (1) to (6), which aim to test whether the commitment to the principles of the UNGC influences the companies' ESG performance. It is worth mentioning that a low variability in the estimates is appreciated after running the models considering the independents in levels and in their first lag. This effect provides greater evidence of the robustness of the relations identified by the models. As shown in this table, the financial control variables (i.e., size, leverage, R\&D intensity) are associated in different ways with the studied measures of firms' ESG performance. 
Table 2. Influence of the commitment to the UNGC on firms' CSP, CEP, and CGP.

\begin{tabular}{|c|c|c|c|c|c|c|c|c|c|c|c|c|}
\hline \multirow[b]{2}{*}{ Constant } & \multicolumn{4}{|c|}{ CSP } & \multicolumn{4}{|c|}{ CEP } & \multicolumn{4}{|c|}{ CGP } \\
\hline & $\begin{array}{l}62.78^{* * *} \\
(14.007)\end{array}$ & $\begin{array}{l}32.45^{* * *} \\
(12.629)\end{array}$ & $\begin{array}{l}58.93^{* * *} \\
(14.861)\end{array}$ & $\begin{array}{l}33.65^{* * *} \\
(13.447)\end{array}$ & $\begin{array}{l}52.06^{* * *} \\
(12.203)\end{array}$ & $\begin{array}{l}29.65^{* * *} \\
(11.582)\end{array}$ & $\begin{array}{l}51.69^{* * *} \\
(12.572)\end{array}$ & $\begin{array}{l}34.59^{* * *} \\
(11.976)\end{array}$ & $\begin{array}{l}61.98^{* * *} \\
(12.042)\end{array}$ & $\begin{array}{c}42.23^{* * *} \\
(10.23)\end{array}$ & $\begin{array}{c}59.02^{* * *} \\
(12.45)\end{array}$ & $\begin{array}{c}45.04^{* * *} \\
(10.34)\end{array}$ \\
\hline UNGC & & $\begin{array}{c}34.35^{* * *} \\
(2.796)\end{array}$ & & $\begin{array}{c}31.57^{* * *} \\
(2.931)\end{array}$ & & $\begin{array}{c}23.96^{* * *} \\
(2.573)\end{array}$ & & $\begin{array}{c}20.25^{* * *} \\
(2.614)\end{array}$ & & $\begin{array}{c}19.52^{* * *} \\
(1.813)\end{array}$ & & $\begin{array}{c}17.41^{* * *} \\
(1.979)\end{array}$ \\
\hline \multicolumn{13}{|c|}{ Financial controls } \\
\hline Size & $\begin{array}{l}-0.433 \\
(0.677)\end{array}$ & $\begin{array}{c}0.675 \\
(0.606)\end{array}$ & & & $\begin{array}{c}0.889 \\
(0.590)\end{array}$ & $\begin{array}{c}1.724 \\
(0.555)\end{array}$ & & & $\begin{array}{c}-4.700^{* * *} \\
(0.431)\end{array}$ & $\begin{array}{c}-4.118^{* * *} \\
(0.394)\end{array}$ & & \\
\hline Leverage & $\begin{array}{c}5.7 \times 10^{-6} \\
(0.0005)\end{array}$ & $\begin{array}{c}1.1 \times 10^{-6} \\
(0.0005)\end{array}$ & & & $\begin{array}{c}7.5 \times 10^{-6} \\
(0.0005)\end{array}$ & $\begin{array}{c}3.9 \times 10^{-6} \\
(0.0005)\end{array}$ & & & $\begin{array}{c}9.3 \times 10^{-6} \\
(0.0003)\end{array}$ & $\begin{array}{c}3.5 \times 10^{-6} \\
(0.0003)\end{array}$ & & \\
\hline $\mathrm{R} \& \mathrm{D}$ intensity & $\begin{array}{c}0.672^{* * *} \\
(0.161)\end{array}$ & $\begin{array}{c}0.691^{* * *} \\
(0.157)\end{array}$ & & & $\begin{array}{c}0.410 \\
(0.142) \\
\end{array}$ & $\begin{array}{c}0.437^{* * *} \\
(0.139)\end{array}$ & & & $\begin{array}{l}-0.033 \\
(0.108)\end{array}$ & $\begin{array}{l}-0.026 \\
(0.106) \\
\end{array}$ & & \\
\hline L1 size & & & $\begin{array}{l}-0.088 \\
(0.720) \\
\end{array}$ & $\begin{array}{c}0.815 \\
(0.647) \\
\end{array}$ & & & $\begin{array}{l}1.059^{*} \\
(0.609) \\
\end{array}$ & $\begin{array}{c}1.682^{* * *} \\
(0.576)\end{array}$ & & & $\begin{array}{c}-4.460^{* * *} \\
(0.469) \\
\end{array}$ & $\begin{array}{c}-3.999^{* * *} \\
(0.437)\end{array}$ \\
\hline L1 leverage & & & $\begin{array}{l}-0.0006 \\
(0.0008)\end{array}$ & $\begin{array}{l}-0.0007 \\
(0.0008)\end{array}$ & & & $\begin{array}{l}-0.0003 \\
(0.0007)\end{array}$ & $\begin{array}{l}-0.0004 \\
(0.0007)\end{array}$ & & & $\begin{array}{c}0.0001 \\
(0.0006)\end{array}$ & $\begin{array}{c}0.0001 \\
(0.0006)\end{array}$ \\
\hline L1 R\&D intensity & & & $\begin{array}{c}0.577^{* * *} \\
(0.182) \\
\end{array}$ & $\begin{array}{c}0.601^{* * *} \\
(0.177) \\
\end{array}$ & & & $\begin{array}{l}0.363^{* *} \\
(0.158)\end{array}$ & $\begin{array}{l}0.393^{* *} \\
(0.156) \\
\end{array}$ & & & $\begin{array}{c}0.056 \\
(0.122) \\
\end{array}$ & $\begin{array}{c}0.065 \\
(0.119) \\
\end{array}$ \\
\hline \multicolumn{13}{|c|}{ Non-financial controls } \\
\hline Consumer cyclicals & $\begin{array}{l}-3.892 \\
(5.308) \\
\end{array}$ & $\begin{array}{l}-4.657 \\
(4.602) \\
\end{array}$ & $\begin{array}{c}1.331 \\
(5.384) \\
\end{array}$ & $\begin{array}{l}-0.183 \\
(4.727) \\
\end{array}$ & $\begin{array}{l}-6.562 \\
(4.618) \\
\end{array}$ & $\begin{array}{l}-7.067 \\
(4.239) \\
\end{array}$ & $\begin{array}{l}-0.388 \\
(4.536) \\
\end{array}$ & $\begin{array}{l}-1.345 \\
(4.215) \\
\end{array}$ & $\begin{array}{c}2.474 \\
(3.349) \\
\end{array}$ & $\begin{array}{c}1.979 \\
(2.982) \\
\end{array}$ & $\begin{array}{c}3.525 \\
(3.492) \\
\end{array}$ & $\begin{array}{c}2.688 \\
(3.192) \\
\end{array}$ \\
\hline $\begin{array}{c}\text { Consumer } \\
\text { non-cyclicals }\end{array}$ & $\begin{array}{l}-9.672 \\
(6.685) \\
\end{array}$ & $\begin{array}{c}-14.11^{* *} \\
(5.809) \\
\end{array}$ & $\begin{array}{l}-6.992 \\
(6.848) \\
\end{array}$ & $\begin{array}{c}-12.52^{* *} \\
(6.032) \\
\end{array}$ & $\begin{array}{c}-16.35^{\text {*** }} \\
(5.816)\end{array}$ & $\begin{array}{c}-19.43^{* * *} \\
(5.35)\end{array}$ & $\begin{array}{c}-14.29^{* *} \\
(5.769)\end{array}$ & $\begin{array}{c}-17.82^{* * *} \\
(5.379)\end{array}$ & $\begin{array}{c}3.978 \\
(4.219)\end{array}$ & $\begin{array}{c}1.422 \\
(3.765)\end{array}$ & $\begin{array}{c}5.435 \\
(4.442)\end{array}$ & $\begin{array}{c}2.364 \\
(4.073)\end{array}$ \\
\hline Energy & $\begin{array}{l}12.120 \\
(8.903)\end{array}$ & $\begin{array}{c}4.111 \\
(7.751) \\
\end{array}$ & $\begin{array}{l}10.253 \\
(9.112) \\
\end{array}$ & $\begin{array}{c}4.177 \\
(8.028)\end{array}$ & $\begin{array}{c}4.682 \\
(7.746) \\
\end{array}$ & $\begin{array}{l}-0.858 \\
(7.138)\end{array}$ & $\begin{array}{c}1.741 \\
(7.679) \\
\end{array}$ & $\begin{array}{l}-2.132 \\
(7.157)\end{array}$ & $\begin{array}{c}17.13^{* * *} \\
(5.620) \\
\end{array}$ & $\begin{array}{l}12.54^{* *} \\
(5.024)\end{array}$ & $\begin{array}{c}15.82^{* * *} \\
(5.913)\end{array}$ & $\begin{array}{l}12.47^{* *} \\
(5.421)\end{array}$ \\
\hline Financials & $\begin{array}{l}-26.24^{* *} \\
(12.786)\end{array}$ & $\begin{array}{l}-21.47^{*} \\
(11.164)\end{array}$ & $\begin{array}{c}-1.847 \\
(21.614) \\
\end{array}$ & $\begin{array}{c}-9.024 \\
(18.965)\end{array}$ & $\begin{array}{c}-33.14^{* * *} \\
(11.129)\end{array}$ & $\begin{array}{c}-29.79^{* * *} \\
(10.261)\end{array}$ & $\begin{array}{c}-25.46 \\
(18.205)\end{array}$ & $\begin{array}{l}-29.97^{*} \\
(16.913)\end{array}$ & $\begin{array}{c}3.671 \\
(8.095) \\
\end{array}$ & $\begin{array}{c}6.245 \\
(7.253) \\
\end{array}$ & $\begin{array}{c}15.48 \\
(14.02) \\
\end{array}$ & $\begin{array}{c}11.47 \\
(12.80) \\
\end{array}$ \\
\hline Healthcare & $\begin{array}{l}-1.990 \\
(7.777) \\
\end{array}$ & $\begin{array}{l}-3.659 \\
(6.787) \\
\end{array}$ & $\begin{array}{c}0.388 \\
(7.647) \\
\end{array}$ & $\begin{array}{l}-1.682 \\
(6.767) \\
\end{array}$ & $\begin{array}{c}-11.36^{*} \\
(6.769)\end{array}$ & $\begin{array}{c}-12.63^{* *} \\
(6.239)\end{array}$ & $\begin{array}{l}-10.17 \\
(6.459) \\
\end{array}$ & $\begin{array}{c}-11.63^{*} \\
(6.029)\end{array}$ & $\begin{array}{r}1.225 \\
(4.925) \\
\end{array}$ & $\begin{array}{c}0.279 \\
(4.409) \\
\end{array}$ & $\begin{array}{r}1.065 \\
(4.973) \\
\end{array}$ & $\begin{array}{l}-0.064 \\
(4.570)\end{array}$ \\
\hline
\end{tabular}


Table 2. Cont.

\begin{tabular}{|c|c|c|c|c|c|c|c|c|c|c|c|c|}
\hline \multirow[b]{2}{*}{ Industrials } & \multicolumn{4}{|c|}{ CSP } & \multicolumn{4}{|c|}{ CEP } & \multicolumn{4}{|c|}{ CGP } \\
\hline & $\begin{array}{c}0.110 \\
(5.108) \\
\end{array}$ & $\begin{array}{l}-4.142 \\
(4.442) \\
\end{array}$ & $\begin{array}{c}3.797 \\
(5.131) \\
\end{array}$ & $\begin{array}{l}-0.901 \\
(4.524) \\
\end{array}$ & $\begin{array}{c}0.529 \\
(4.444) \\
\end{array}$ & $\begin{array}{l}-2.410 \\
(4.091) \\
\end{array}$ & $\begin{array}{c}4.297 \\
(4.323) \\
\end{array}$ & $\begin{array}{c}1.311 \\
(4.034) \\
\end{array}$ & $\begin{array}{c}4.382 \\
(3.223) \\
\end{array}$ & $\begin{array}{c}1.922 \\
(2.877) \\
\end{array}$ & $\begin{array}{c}4.285 \\
(3.328) \\
\end{array}$ & $\begin{array}{c}1.712 \\
(3.055) \\
\end{array}$ \\
\hline Technology & $\begin{array}{r}-3.046 \\
(6.200) \\
\end{array}$ & $\begin{array}{r}-6.989 \\
(5.387) \\
\end{array}$ & $\begin{array}{c}0.641 \\
(6.154) \\
\end{array}$ & $\begin{array}{l}-4.204 \\
(5.426) \\
\end{array}$ & $\begin{array}{r}-6.312 \\
(5.394) \\
\end{array}$ & $\begin{array}{l}-9.099 * \\
(4.9615) \\
\end{array}$ & $\begin{array}{r}-3.563 \\
(5.187) \\
\end{array}$ & $\begin{array}{r}-6.718 \\
(4.837) \\
\end{array}$ & $\begin{array}{c}4.004 \\
(3.914) \\
\end{array}$ & $\begin{array}{c}1.741 \\
(3.492) \\
\end{array}$ & $\begin{array}{r}4.779 \\
(3.993) \\
\end{array}$ & $\begin{array}{r}2.115 \\
(3.664) \\
\end{array}$ \\
\hline Telecomm. Services & $\begin{array}{c}8.204 \\
(11.798)\end{array}$ & $\begin{array}{c}3.616 \\
(10.237) \\
\end{array}$ & $\begin{array}{c}5.220 \\
(12.092) \\
\end{array}$ & $\begin{array}{c}3.169 \\
(10.608) \\
\end{array}$ & $\begin{array}{c}-6.065 \\
(10.265) \\
\end{array}$ & $\begin{array}{l}-9.285 \\
(9.429) \\
\end{array}$ & $\begin{array}{c}-9.830 \\
(10.185) \\
\end{array}$ & $\begin{array}{l}-11.15 \\
(9.460) \\
\end{array}$ & $\begin{array}{l}14.83^{* *} \\
(7.446)\end{array}$ & $\begin{array}{l}12.19^{*} \\
(6.633)\end{array}$ & $\begin{array}{c}9.368 \\
(7.842)\end{array}$ & $\begin{array}{c}8.254 \\
(7.163)\end{array}$ \\
\hline Utilities & $\begin{array}{c}4.873 \\
(8.359) \\
\end{array}$ & $\begin{array}{c}1.863 \\
(7.257)\end{array}$ & $\begin{array}{l}-2.682 \\
(8.664) \\
\end{array}$ & $\begin{array}{l}-4.280 \\
(7.606) \\
\end{array}$ & $\begin{array}{c}3.313 \\
(7.273)\end{array}$ & $\begin{array}{c}1.244 \\
(6.683) \\
\end{array}$ & $\begin{array}{l}-0.269 \\
(7.299)\end{array}$ & $\begin{array}{l}-1.312 \\
(6.783) \\
\end{array}$ & $\begin{array}{l}11.24^{* *} \\
(5.277)\end{array}$ & $\begin{array}{l}9.572^{* *} \\
(4.704)\end{array}$ & $\begin{array}{c}6.921 \\
(5.620) \\
\end{array}$ & $\begin{array}{c}6.094 \\
(5.136) \\
\end{array}$ \\
\hline \multicolumn{13}{|l|}{ Time effects } \\
\hline 2009 & $\begin{array}{c}2.822^{* * *} \\
(0.757) \\
\end{array}$ & $\begin{array}{c}2.890^{* * *} \\
(0.755) \\
\end{array}$ & & & $\begin{array}{c}2.196^{* * *} \\
(0.666) \\
\end{array}$ & $\begin{array}{c}2.244^{* * *} \\
(0.666) \\
\end{array}$ & & & $\begin{array}{c}1.799^{* * *} \\
(0.515) \\
\end{array}$ & $\begin{array}{c}1.835^{* * *} \\
(0.514) \\
\end{array}$ & & \\
\hline 2010 & $\begin{array}{c}3.131^{* * *} \\
(0.753) \\
\end{array}$ & $\begin{array}{c}3.169^{* * *} \\
(0.751) \\
\end{array}$ & $\begin{array}{l}-0.105 \\
(0.711) \\
\end{array}$ & $\begin{array}{r}0.030 \\
(0.709) \\
\end{array}$ & $\begin{array}{c}3.188^{* * *} \\
(0.663) \\
\end{array}$ & $\begin{array}{c}3.218^{* * *} \\
(0.662) \\
\end{array}$ & $\begin{array}{c}0.771 \\
(0.623) \\
\end{array}$ & $\begin{array}{c}0.797 \\
(0.623) \\
\end{array}$ & $\begin{array}{c}5.132^{* * *} \\
(0.512) \\
\end{array}$ & $\begin{array}{c}5.154^{* * *} \\
(0.512) \\
\end{array}$ & $\begin{array}{c}2.861^{* * *} \\
(0.481) \\
\end{array}$ & $\begin{array}{c}2.882^{* * *} \\
(0.480)\end{array}$ \\
\hline 2011 & $\begin{array}{c}5.332^{* * *} \\
(0.756) \\
\end{array}$ & $\begin{array}{c}5.343^{* * *} \\
(0.755) \\
\end{array}$ & $\begin{array}{c}2.259^{* * *} \\
(0.710)\end{array}$ & $\begin{array}{c}2.279^{* * *} \\
(0.709) \\
\end{array}$ & $\begin{array}{c}4.489^{* * *} \\
(0.665) \\
\end{array}$ & $\begin{array}{c}4.503^{* * *} \\
(0.665) \\
\end{array}$ & $\begin{array}{c}2.133^{* * *} \\
(0.623)\end{array}$ & $\begin{array}{c}2.150^{* * *} \\
(0.623)\end{array}$ & $\begin{array}{c}4.913^{* * *} \\
(0.515) \\
\end{array}$ & $\begin{array}{c}4.920^{* * *} \\
(0.514) \\
\end{array}$ & $\begin{array}{c}2.691^{* * *} \\
(0.480)\end{array}$ & $\begin{array}{c}2.701^{* * *} \\
(0.480)\end{array}$ \\
\hline 2012 & $\begin{array}{c}3.847^{* * *} \\
(0.753) \\
\end{array}$ & $\begin{array}{c}3.787^{* * *} \\
(0.752) \\
\end{array}$ & $\begin{array}{c}0.825 \\
(0.712) \\
\end{array}$ & $\begin{array}{c}0.828 \\
(0.711) \\
\end{array}$ & $\begin{array}{c}3.850^{* * *} \\
(0.663) \\
\end{array}$ & $\begin{array}{c}3.802^{* * *} \\
(0.663) \\
\end{array}$ & $\begin{array}{l}1.552^{* *} \\
(0.624) \\
\end{array}$ & $\begin{array}{l}1.558^{* *} \\
(0.624) \\
\end{array}$ & $\begin{array}{l}1.293^{* *} \\
(0.513) \\
\end{array}$ & $\begin{array}{l}1.250^{* *} \\
(0.512) \\
\end{array}$ & $\begin{array}{c}-1.039^{* *} \\
(0.481) \\
\end{array}$ & $\begin{array}{c}-1.038^{* *} \\
(0.481) \\
\end{array}$ \\
\hline 2013 & $\begin{array}{c}4.996^{* * *} \\
(0.766)\end{array}$ & $\begin{array}{c}4.861^{* * *} \\
(0.764)\end{array}$ & $\begin{array}{c}2.122^{* * *} \\
(0.726)\end{array}$ & $\begin{array}{c}2.146^{* * *} \\
(0.724)\end{array}$ & $\begin{array}{c}4.329^{* * *} \\
(0.674)\end{array}$ & $\begin{array}{c}4.217^{* * *} \\
(0.674)\end{array}$ & $\begin{array}{c}2.285^{* * *} \\
(0.637)\end{array}$ & $\begin{array}{c}2.232^{* * *} \\
(0.637)\end{array}$ & $\begin{array}{l}1.218^{* *} \\
(0.521)\end{array}$ & $\begin{array}{l}1.185^{* *} \\
(0.520)\end{array}$ & $\begin{array}{c}-1.412^{* * *} \\
(0.491)\end{array}$ & $\begin{array}{c}-1.454^{* * *} \\
(0.490)\end{array}$ \\
\hline
\end{tabular}

This table shows the estimates of the unbalanced panel data represented by Equations (1) to (6), which aim to test whether the firms' commitment to the UNGC has an influence on their environmental, social and governance (ESG) performance levels. $\mathrm{N}=396$. Values in parentheses are robust standard errors to heteroscedasticity.

${ }^{* * *}$ Significant at $1 \%,{ }^{* *}$ Significant at $5 \%,{ }^{*}$ Significant at $10 \%$. 
Specifically, the higher the companies' R\&D intensity ratio, the higher their levels of CSP and CEP. Conversely, this ratio seems not to have a significant impact on CGP levels. Furthermore, the greater the companies' size, the higher their CEP levels and the lower their CGP. The estimates also show that companies' leverage ratio does not have a significant impact on their ESG performance. The economic sector in which the companies operate seems to not play a fundamental role in explaining companies' ESG performance. However, the following trends have been identified: (a) companies operating in financials and in consumer non-cyclicals obtained lower levels of CSP and CEP than the baseline industry (i.e., basic materials), and (b) companies involved in energy, telecommunication services, and utilities significantly outperform the basic materials firms in terms of CGP. The time effects are mostly significant, thus indicating that the firms' CSP, CEP, and CGP are influenced by the different time periods considered in the panels. The positive/negative sign of the time effects coefficients should be interpreted since the companies obtained higher/lower levels of ESG performance when compared with the baseline period (i.e., 2008).

More interestingly, the coefficients related to the UNGC variable are positive and significant. It is worth mentioning that these coefficients are significant at $1 \%$ and when considering both the in-levels and lagged exogenous variables. This clearly indicates that the firms' commitment to the principles established by the UNGC positively influences the companies' levels of ESG performance. Thus, H1 cannot be rejected. It is interesting to note that the magnitude of the UNGC coefficients vary across the different measures of companies' ESG performance. In fact, the greater impact of the commitment to the UNGC is observed on the firms' social dimension. This result can be explained by the fact that the UNGC mostly focuses on social issues: six of its 10 principles are related to social issues. Moreover, the lower influence of firms' commitment to the UNGC causes the companies' CGP to increase.

Table 3 shows the estimates of the Equations (7) to (11), which aimed to test the possible bidirectional relationships between the two measures of CFP (i.e., TQ and ROA) and the firm's level of ESG performance. Some interesting insights that can be derived from this table warrant comment. As shown in the previous models, the financial controls are associated in different ways with the proposed measures of the firms' ESG performance. It is interesting to note that these associations seem to be quite stable after the companies' ROA and TQ are included as predictors, which confirms the robustness of the models. Moreover, the sector effects are similar to those identified when testing the H1 hypothesis. Again, some of the time effects are significant, indicating that the companies' ESG performance is influenced by the time period examined. There are also interactions between the financial control variables and the two proposed measures of CFP. In fact, the greater the companies' size, the lower their TQ and ROA. Furthermore, the leverage and R\&D intensity ratios seem to have a negative impact on companies' ROA. More interesting for the purposes of this research, Table 3 shows that companies' CEP and CSP levels have a positive influence on companies' TQ and ROA. The higher impact of these measures on companies' CFP is appreciated in the CEP dimension. However, a bidirectional link is only found between firms' CSP and TQ, which is due to the fact that the companies' TQ does not significantly explain the companies' level of CEP. Firms' CEP and CGP levels have a positive and significant effect on firms' ROA. Interestingly, the impact of CEP on companies' ROA is higher than the effect associated with the firms' CGP levels. However, a bidirectional link is only found between firms' CEP and ROA, which is due to the fact that companies' ROA does not significantly explain the companies' level of CGP. The estimates also show that the 
higher the companies' ROA ratio, the higher their CSP levels. These considerations support the H2 and H3 hypotheses.

Table 3. Bidirectional linkages between firms' financial performance and their CSP, CEP, and CGP.

\begin{tabular}{|c|c|c|c|c|c|}
\hline & TQ & ROA & CSP & CEP & CGP \\
\hline Constant & $\begin{array}{c}2.154^{* * *} \\
(0.229)\end{array}$ & $\begin{array}{c}14.10^{* * *} \\
(3.142)\end{array}$ & $\begin{array}{l}65.04^{* * *} \\
(13.534)\end{array}$ & $\begin{array}{l}58.23^{* * *} \\
(12.234)\end{array}$ & $\begin{array}{l}65.34^{* * *} \\
(13.936)\end{array}$ \\
\hline L1 CEP & $\begin{array}{c}0.0423^{* * *} \\
(0.0061)\end{array}$ & $\begin{array}{c}0.034^{* * *} \\
(0.002)\end{array}$ & & & \\
\hline L1 CSP & $\begin{array}{l}0.0157^{* *} \\
(0.0064)\end{array}$ & $\begin{array}{l}-0.004 \\
(0.014)\end{array}$ & & & \\
\hline L1 CGP & $\begin{array}{c}0.0009 \\
(0.0007) \\
\end{array}$ & $\begin{array}{c}0.013^{\text {*** }} \\
(0.004)\end{array}$ & & & \\
\hline L1 TQ & & & $\begin{array}{l}2.822^{* *} \\
(1.189)\end{array}$ & $\begin{array}{l}-0.498 \\
(1.568)\end{array}$ & $\begin{array}{c}0.160 \\
(0.612)\end{array}$ \\
\hline L1 ROA & & & $\begin{array}{l}0.159^{*} \\
(0.085) \\
\end{array}$ & $\begin{array}{l}0.163^{* *} \\
(0.084) \\
\end{array}$ & $\begin{array}{c}0.058 \\
(0.041) \\
\end{array}$ \\
\hline \multicolumn{6}{|c|}{ Financial controls } \\
\hline L1 size & $\begin{array}{c}-0.429^{* * *} \\
(0.010)\end{array}$ & $\begin{array}{c}-0.279^{*} \\
(0.144) \\
\end{array}$ & $\begin{array}{l}2.322^{* *} \\
(1.024) \\
\end{array}$ & $\begin{array}{l}2.250^{* *} \\
(0.873) \\
\end{array}$ & $\begin{array}{c}-3.154^{* * *} \\
(0.478)\end{array}$ \\
\hline L1 leverage & $\begin{array}{c}2 \times 10^{-6} \\
\left(9 \times 10^{-7}\right)\end{array}$ & $\begin{array}{c}-0.0001^{* * *} \\
(0.00001) \\
\end{array}$ & $\begin{array}{l}-0.0004 \\
(0.0009) \\
\end{array}$ & $\begin{array}{l}-0.0004 \\
(0.0007) \\
\end{array}$ & $\begin{array}{l}-0.0006 \\
(0.0004)\end{array}$ \\
\hline L1 R\&D intensity & $\begin{array}{l}-0.005 \\
(0.004)\end{array}$ & $\begin{array}{c}-0.198^{* * *} \\
(0.070)\end{array}$ & $\begin{array}{c}0.698^{* * *} \\
(0.220)\end{array}$ & $\begin{array}{c}0.615^{* * *} \\
(0.192)\end{array}$ & $\begin{array}{c}0.014 \\
(0.112)\end{array}$ \\
\hline \multicolumn{6}{|c|}{ Non-financial controls } \\
\hline Consumer cyclicals & $\begin{array}{l}-0.065 \\
(0.093) \\
\end{array}$ & $\begin{array}{l}-1.305 \\
(1.200) \\
\end{array}$ & $\begin{array}{c}0.318 \\
(6.077) \\
\end{array}$ & $\begin{array}{l}-0.231 \\
(5.487) \\
\end{array}$ & $\begin{array}{l}-1.103 \\
(2.937) \\
\end{array}$ \\
\hline Consumer non-cyclicals & $\begin{array}{c}0.289^{* * *} \\
(0.106)\end{array}$ & $\begin{array}{c}1.089 \\
(1.361) \\
\end{array}$ & $\begin{array}{c}-25.11^{* * *} \\
(8.310) \\
\end{array}$ & $\begin{array}{c}-28.18^{* * *} \\
(7.504)\end{array}$ & $\begin{array}{c}-6.884^{*} \\
(3.893) \\
\end{array}$ \\
\hline Energy & $\begin{array}{l}-0.063 \\
(0.125) \\
\end{array}$ & $\begin{array}{c}0.078 \\
(1.616) \\
\end{array}$ & $\begin{array}{c}6.915 \\
(11.44) \\
\end{array}$ & $\begin{array}{c}1.225 \\
(10.34) \\
\end{array}$ & $\begin{array}{c}11.595^{* *} \\
(5.736)\end{array}$ \\
\hline Financials & $\begin{array}{l}-0.215 \\
(0.283) \\
\end{array}$ & $\begin{array}{l}-4.446 \\
(3.576) \\
\end{array}$ & $\begin{array}{l}-33.38 \\
(29.46) \\
\end{array}$ & $\begin{array}{l}-34.93 \\
(26.60) \\
\end{array}$ & $\begin{array}{c}0.541 \\
(6.735) \\
\end{array}$ \\
\hline Healthcare & $\begin{array}{c}0.654^{* * *} \\
(0.132) \\
\end{array}$ & $\begin{array}{c}4.793^{* * *} \\
(1.740) \\
\end{array}$ & $\begin{array}{l}-2.330 \\
(8.921) \\
\end{array}$ & $\begin{array}{c}-14.31^{*} \\
(8.066) \\
\end{array}$ & $\begin{array}{l}-1.893 \\
(4.497) \\
\end{array}$ \\
\hline Industrials & $\begin{array}{l}-0.051 \\
(0.086)\end{array}$ & $\begin{array}{l}-0.932 \\
(1.098)\end{array}$ & $\begin{array}{l}-3.616 \\
(5.927)\end{array}$ & $\begin{array}{c}2.876 \\
(5.352)\end{array}$ & $\begin{array}{l}-0.521 \\
(2.899)\end{array}$ \\
\hline Technology & $\begin{array}{c}0.046 \\
(0.101) \\
\end{array}$ & $\begin{array}{l}-1.929 \\
(1.294) \\
\end{array}$ & $\begin{array}{l}-4.332 \\
(7.264) \\
\end{array}$ & $\begin{array}{l}-8.820 \\
(6.561) \\
\end{array}$ & $\begin{array}{c}1.008 \\
(3.568) \\
\end{array}$ \\
\hline Telecomm. Services & $\begin{array}{c}0.293 \\
(0.182) \\
\end{array}$ & $\begin{array}{c}1.255 \\
(2.370) \\
\end{array}$ & $\begin{array}{c}5.500 \\
(14.04) \\
\end{array}$ & $\begin{array}{l}-11.01 \\
(12.68) \\
\end{array}$ & $\begin{array}{c}6.638 \\
(7.060) \\
\end{array}$ \\
\hline Utilities & $\begin{array}{l}-0.081 \\
(0.141)\end{array}$ & $\begin{array}{l}-0.617 \\
(1.857) \\
\end{array}$ & $\begin{array}{l}-9.875 \\
(9.847)\end{array}$ & $\begin{array}{l}-4.282 \\
(8.893) \\
\end{array}$ & $\begin{array}{c}3.248 \\
(4.786)\end{array}$ \\
\hline
\end{tabular}


Table 3. Cont.

\begin{tabular}{cccccc}
\hline & TQ & ROA & CSP & CEP & CGP \\
\hline Time effects & & & & & \\
\hline \multirow{2}{*}{2010} & -0.008 & $-1.407^{* * *}$ & 0.992 & 0.456 & $3.930^{* * *}$ \\
& $(0.024)$ & $(0.455)$ & $(0.972)$ & $(0.894)$ & $(1.150)$ \\
\hline \multirow{2}{*}{2011} & $-0.099^{* * *}$ & $-0.866^{*}$ & $2.992^{* * *}$ & $3.129^{* * *}$ & $4.030^{* * *}$ \\
& $(0.024)$ & $(0.455)$ & $(0.940)$ & $(0.865)$ & $(1.063)$ \\
\hline \multirow{2}{*}{2012} & $-0.085^{* * *}$ & $-1.655^{* * *}$ & 0.622 & $1.542^{*}$ & -0.577 \\
& $(0.023)$ & $(0.448)$ & $(0.946)$ & $(0.870)$ & $(1.065)$ \\
\hline \multirow{2}{*}{2013} & -0.007 & $-1.863^{* * *}$ & $2.265^{* *}$ & $2.289^{* *}$ & $-1.895^{*}$ \\
& $(0.024)$ & $(0.447)$ & $(0.978)$ & $(0.900)$ & $(1.108)$ \\
\hline
\end{tabular}

This table shows the estimates of the unbalanced panel data represented by Equations (7) to (11), which aim to test the links between firms' environmental, social, and governance (ESG) performance and the CFP of the companies committed to the UNGC. $\mathrm{N}=198$. Values in parentheses are robust standard errors to heteroscedasticity. ${ }^{* *}$ Significant at $1 \%,{ }^{* *}$ Significant at $5 \%,{ }^{*}$ Significant at $10 \%$.

Table 4 shows the estimates that will allow us to identify whether companies' geographical spread plays a role as a moderator in the relationship between firms' ESG and financial performance. The financial controls, sector, and time effects are shown briefly for brevity purposes. As shown in the table, some interactions are found when introducing the country as a moderator variable. First, the country variable seems to play an important role in the impact that the firms' CEP has on their TQ. This is because both the main effect and the interaction between CEP and country on TQ are positive and significant. Specifically, the magnitude of the coefficients clearly indicates that those companies operating in Japan have the higher impact of CEP on their TQ. Conversely, the magnitude of the relationship between companies' CEP and ROA is lower for the Japanese companies. Another interesting finding is that the impact of firms' CSP on their TQ is greater in Spanish than in French and Japanese companies. The influence of firms' CGP on their ROA seems to be of a similar magnitude in both Spanish and French companies, whereas the impact is significantly higher for Japanese firms. Companies' TQ influence on their CSP levels is significantly higher in the case of Japanese and French companies, but has the highest effect in companies operating in Japan. It is interesting to note that the impact of companies' ROA on CSP does not differ across the three countries examined. Finally, the positive impact of firms' ROA on their levels of CEP is higher in the case of the Japanese companies. These different associations can be explained by the following reasons: (1) a Christian versus a Confucian cultural background may lead to a different emphasis on social versus environmental priorities, and (2) differences in the cultural and institutional settings. 
Table 4. The role of country as a moderator variable.

\begin{tabular}{|c|c|c|c|c|}
\hline & TQ & ROA & CSP & CEP \\
\hline Constant & $\begin{array}{c}2.345^{* * *} \\
(0.301)\end{array}$ & $\begin{array}{c}12.02^{* * *} \\
(2.734)\end{array}$ & $\begin{array}{l}63.82^{* * *} \\
(12.622)\end{array}$ & $\begin{array}{l}55.91^{* * *} \\
(12.066)\end{array}$ \\
\hline L1 CEP & $\begin{array}{c}0.0253^{* * *} \\
(0.0045) \\
\end{array}$ & $\begin{array}{c}0.019^{* * *} \\
(0.002)\end{array}$ & & \\
\hline L1 CEP ${ }^{*}$ France & $\begin{array}{c}0.0004 \\
(0.0623)\end{array}$ & $\begin{array}{c}0.0014 \\
(0.0402)\end{array}$ & & \\
\hline L1 CEP ${ }^{*}$ Japan & $\begin{array}{c}0.1235^{* * *} \\
(0.0034)\end{array}$ & $\begin{array}{c}-0.026^{* * *} \\
(0.0001)\end{array}$ & & \\
\hline L1 CSP & $\begin{array}{c}0.0124^{* * *} \\
(0.0014)\end{array}$ & & & \\
\hline L1 $\mathrm{CSP}^{*}$ France & $\begin{array}{c}-0.018^{* * *} \\
(0.0001)\end{array}$ & & & \\
\hline L1 CSP ${ }^{*}$ Japan & $\begin{array}{c}-0.035^{\text {*** }} \\
(0.0001)\end{array}$ & & & \\
\hline L1 CGP & & $\begin{array}{c}0.0125^{\text {*** }} \\
(0.003) \\
\end{array}$ & & \\
\hline L1 CGP ${ }^{*}$ France & & $\begin{array}{c}0.0023 \\
(0.0475) \\
\end{array}$ & & \\
\hline L1 CGP * Japan & & $\begin{array}{c}0.0157^{* * *} \\
(0.0003)\end{array}$ & & \\
\hline L1 TQ & & & $\begin{array}{c}1.429^{* * *} \\
(0.734)\end{array}$ & \\
\hline L1 TQ ${ }^{*}$ France & & & $\begin{array}{c}1.0184^{* * *} \\
(0.0023)\end{array}$ & \\
\hline L1 TQ * Japan & & & $\begin{array}{c}1.7831^{* * *} \\
(0.871)\end{array}$ & \\
\hline L1 ROA & & & $\begin{array}{l}0.1411^{*} \\
(0.0751)\end{array}$ & $\begin{array}{c}0.2371^{* * *} \\
(0.024)\end{array}$ \\
\hline L1 ROA * France & & & $\begin{array}{l}0.0026 \\
(0.012) \\
\end{array}$ & $\begin{array}{c}0.0001 \\
(0.0025)\end{array}$ \\
\hline L1 ROA * Japan & & & $\begin{array}{c}0.0021 \\
(0.294)\end{array}$ & $\begin{array}{l}0.0991^{* *} \\
(0.0510)\end{array}$ \\
\hline
\end{tabular}

\begin{tabular}{ccccc}
\hline Financial controls effect & YES $^{* * *}$ & YES $^{* * *}$ & YES $^{* * *}$ & YES $^{* * *}$ \\
\hline Sector effect & YES $^{* * *}$ & YES $^{* * *}$ & YES $^{* * *}$ & YES $^{* * *}$ \\
\hline Time effect & YES $^{* * *}$ & YES $^{* * *}$ & YES $^{* * *}$ & YES $^{* * *}$ \\
\hline
\end{tabular}

This table shows the estimates of the unbalanced panel data, which aims to test whether, for firms committed to the UNGC, the country in which the companies operate moderates the relationship between their environmental, social, and governance (ESG) performance and their CFP. $\mathrm{N}=198$. Values in parentheses are robust standard errors to heteroscedasticity. ${ }^{* * *}$ Significant at $1 \%,{ }^{* *}$ Significant at $5 \%,{ }^{*}$ Significant at $10 \%$. 


\section{Conclusions}

Corporate social responsibility initiatives are expected to systematically encourage cultural and managerial changes in companies committed to sustainable development, human rights, and social well-being. This paper investigates a specific CSR mechanism-the United Nations Global Compact - to shed some light on the impact of UNGC commitment on corporations' environmental, social, and governance (ESG) performance. Additionally, this work analyzes the possible bidirectional relationship between firms' ESG performance and their financial performance (CFP) through several panels of data covering companies operating in the three countries that have the highest rate of companies committed to the UNGC: Spain, France, and Japan. This analysis will show essential information to improve companies' sustainable strategic management policies. Finally, we test for the possible appearance of a country moderation effect in the aforementioned relationships.

As the empirical analysis shows, the commitment of the companies to the UNGC has a positive and significant impact on firms' ESG performance. It is worth mentioning that this link is observed during the negative and highly controversial economic setting covered by the sample-from 2008-2013, in which the global economy entered a period of deep recession-thus indicating that the positive implications of firms' commitment to the UNGC are present even in bear market periods. This finding is of special interest as it demonstrates that the adoption of this voluntary CSR initiative will systematically improve companies' ESG performance and thus have a positive effect on environmental preservation, human well-being, social justice, and sustainable development. In fact, companies will have non-financial incentives to adopt the UNGC that will result in a more coherent and sustainable development of community and society. The positive effect on corporations' ESG performance due to their adoption of the UNGC can be explained by the fact that the commitment necessarily involves an organizational change that allows stakeholder engagement, universal rights, sustainable development, and the common good to flourish.

Another interesting finding of this paper is the fact that those companies' committed to the UNGC saw a significant and positive relationship between their ESG performance and their CFP, as measured by the companies' TQ and ROA. Thus, it appears reasonable to say that those companies that do not actually consider the UNGC should be encouraged to adopt this voluntary CSR initiative, which will allow them, at the same time, to improve their ESG performance and their financial success. Moreover, a bidirectional link has been found between the different measures of companies' ESG performance and their CFP, thus demonstrating the existence of a virtuous circle that can stimulate either the firms' financial or ESG success. These findings are consistent with the premises of both the good management and slack resources theories. These considerations are of essential importance because, in the absence of firms' non-financial incentives to adopt the UNGC, financial incentives can encourage compact commitment that will ultimately result, as indicated in this paper, in setting up collaborative solutions to support broadly accepted societal and environmental objectives.

The relationships identified between companies' ESG performance and CFP are moderated in different ways by the geographical spread in which the companies operate. It is interesting to note that despite the appearance of the moderation effects, the final observed linkages between firms' ESG performance and CFP remain positive. This finding clearly indicates that the geographical spread in which companies develop their businesses is not an obstacle to obtaining the financial advantages of 
the firms' adoption and commitment of the principles established by the UNGC. Interestingly, this research provides evidence of the appearance of some positive moderating effects in the mentioned relationships, thus showing differences in the positive influence of firms' ESG performance on CFP depending on the country in which the companies develop their business activity. Those findings are very important when establishing sustainable corporate strategic management policies. This is because, although sustainable development is a global concern, firms' managers should take into account differences in countries' cultural, institutional, and social differences to properly achieve corporate financial and non-financial objectives.

\section{Acknowledgments}

The authors are grateful for the financial help from the Spanish Ministry of Science and Innovation (research project ECO2011-26171). The usual disclaimer applies.

\section{Author Contributions}

Eduardo Ortas and Igor Álvarez were involved in the conception and design of the experiments and also analyzed the data. Eduardo Ortas performed the experiments and all authors wrote the paper. Eduardo Ortas contributed research materials and analysis tools. Ainhoa Garayar and Igor Álvarez participated in the literature review and theoretical foundations. All authors gave thought to the conclusions. All authors read and approved the submitted manuscript.

\section{Conflicts of Interest}

The authors declare no conflicts of interest.

\section{References}

1. Rasche, A.; Waddock, S.; Mclntosh, M. The United Nations Global Compact: Retrospect and prospect. Bus. Soc. 2013, 52, 6-30.

2. Etzion, D.; Ferraro, F. The role of analogy in the institutionalization of sustainability reporting. Organ. Sci. 2010, 21, 1092-1107.

3. Gilbert, D.U.; Rasche, A. Discourse ethics and social accountability: The ethics of SA 8000. Bus. Ethics Q. 2007, 17, 187-216.

4. Christmann, P.; Taylor, G. Firm self-regulation through international certifiable standards: Determinants of symbolic versus substantive implementation. J. Int. Bus. Stud. 2006, 37, 863-878.

5. Kell, G. 12 years later: Reflections on the growth of the UN Global Compact. Bus. Soc. 2013, 52, 31-52.

6. Rasche, A.; Gilbert, D.U. Institutionalizing global governance: The role of the United Nations Global Compact. Bus. Ethics Eur. Rev. 2012, 21, 100-114.

7. Leipziger, D. The Corporate Responsibility Code Book; Greenleaf Publishing: Sheffield, UK, 2010.

8. Cetindamar, D. Corporate social responsibility practices and environmentally responsible behavior: The case of the United Nations Global Compact. J. Bus. Ethics 2007, 76, 163-176. 
9. Ottaway, M. Corporatism goes global: International organizations, nongovernmental organization networks, and transnational business. Glob. Gov. 2001, 7, 265.

10. Ruggie, J.G. Reconstituting the global public domain-issues, actors, and practices. Eur. J. Int. Relat. 2004, 10, 499-531.

11. Arevalo, J.A.; Aravind, D.; Ayuso, S.; Roca, M. The Global Compact: An analysis of the motivations of adoption in the Spanish context. Bus. Ethics Eur. Rev. 2013, 22, 1-15.

12. Rasche, A. A necessary supplement: What the United Nations Global Compact is and is not. Bus. Soc. 2009, 48, 511-537.

13. Ählström, J. Corporate response to CSO criticism: Decoupling the corporate responsibility discourse from business practice. Corp. Soc. Responsib. Environ. Manag. 2010, 17, 70-80.

14. Schwartz, B.; Tilling, K. 'ISO-lating' corporate social responsibility in the organizational context: A dissenting interpretation of ISO 26000. Corp. Soc. Responsib. Environ. Manag. 2009, 16, 289-299.

15. Waddock, S.A.; Graves, S.B. The corporate social performance. Strateg. Manag. J. 1997, 18, 303-319.

16. Kell, G.; Levin, D. The Global Compact network: An historic experiment in learning and action. Bus. Soc. Rev. 2003, 108, 151-181.

17. Berliner, D.; Prakash, A. From norms to programs: The United Nations Global Compact and global governance. Regul. Gov. 2012, 6, 149-166.

18. Ruggie, J.G. Business and human rights: The evolving international agenda. Am. J. Int. Law 2007, $101,819-840$.

19. Ruggie, J.G. Trade, sustainability and global governance. Columbia J. Environ. Law 2002, 27, 297-307.

20. Soederberg, S. Taming corporations or buttressing market-led development? A critical assessment of the Global Compact. Globalizations 2007, 4, 500-513.

21. Runhaar, H.; Lafferty, H. Governing corporate social responsibility: An assessment of the contribution of the UN Global Compact to CSR strategies in the telecommunications industry. J. Bus. Ethics 2009, 84, 479-495.

22. United Nations Global Compact. Annual Review; United Nations Global Compact Office: New York, NY, USA, 2010.

23. United Nations Global Compact. Annual Review; United Nations Global Compact Office: New York, NY, USA, 2012.

24. Harms, D.; Hörisch J.; Schaltegger, S.; Windolph, S.E. International Corporate Sustainability Barometer: Introduction and Structure. In Corporate Sustainability in International Comparison; Springer International Publishing: New York, NY, USA, 2014; pp. 3-12.

25. Moneva, J.M.; Ortas, E.; Álvarez, I. Exploring Sustainability in Spanish Companies. In Corporate Sustainability in International Comparison; Springer International Publishing: New York, NY, USA, 2014; pp. 167-182.

26. Rhouma, A.B.; Francoeur, C.; Robin, G. International Corporate Sustainability Barometer 2012: Sustainability Management in France. In Corporate Sustainability in International Comparison; Springer International Publishing: New York, NY, USA, 2014; pp. 69-91. 
27. Kokubu, K.; Kitada, H.; Haider, M.B. Corporate Sustainability Barometer in Japan. In Corporate Sustainability in International Comparison; Springer International Publishing: New York, NY, USA, 2014; pp. 121-140.

28. Lockett, A.; Moon, J.; Visser, W. Corporate social responsibility in management research: Focus, nature, salience and sources of influence. J. Manag. Stud. 2006, 43, 115-136.

29. Scholtens, B. A note on the interaction between corporate social responsibility and financial performance. Ecol. Econ. 2008, 68, 46-55.

30. Margolis, J.D.; Elfenbein, H.A.; Walsh, J.P. Does it Pay to be Good? A Meta-Analysis and Redirection of Research on the Relationship between Corporate Social and Financial Performance; Working paper; Harvard University: Cambridge, MA, USA, 2007.

31. Orlitzky, M.; Schmidt, F.L.; Rynes, S.L. Corporate social and financial performance: A meta-analysis. Organ. Stud. 2003, 24, 403-441.

32. Hahn, T.; Figge, F. Beyond the bounded instrumentality in current corporate sustainability research: Toward an inclusive notion of profitability. J. Bus. Ethics 2011, 104, 325-345.

33. Ortas, E.; Moneva, J.M.; Álvarez, I. Sustainable supply chain and company performance: A global examination. Supply Chain Manag. Int. J. 2014, 19, 332-350.

34. Schaltegger, S.; Synnestvedt, T. The link between 'green' and economic success: Environmental management as the crucial trigger between environmental and economic performance. J. Environ. Manag. 2002, 65, 339-346.

35. Berger, I.E.; Cunningham, P.; Drumwright, M.E. Mainstreaming corporate social responsibility: Developing markets for virtue. Calif. Manag. Rev. 2007, 49, 132-157.

36. Donaldson, T.; Preston, L.E. The stakeholder theory of the corporation: Concepts, evidence, and implications. Acad. Manag. Rev. 1995, 20, 65-91.

37. Jones, T.M. Instrumental stakeholder theory: A synthesis of ethics and economics. Acad. Manag. Rev. 1995, 20, 404-437.

38. Anderson, J.C.; Frankle, A.W. Voluntary social reporting: An iso-beta portfolio analysis. Account. Rev. 1980, 55, 467-479.

39. Berman, S.L.; Wicks, A.C.; Kotha, S.; Jones, T.M. Does stakeholder orientation matter? The relationship between stakeholder management models and firm financial performance. Acad. Manag. J. 1999, 42, 488-506.

40. Freedman, M.; Stagliano, A.J. Differences in social-cost disclosures: A market test of investor reactions. Account. Audit. Account. J. 1991, 4, 68-83.

41. Graves, S.B.; Waddock, S.A. Beyond built to last stakeholder relations in "Built-to-Last" companies. Bus. Soc. Rev. 2000, 105, 393-418.

42. Griffin, J.J.; Mahon, J.F. The corporate social performance and corporate financial performance debate: Twenty-Five years of incomparable research. Bus. Soc. 1997, 36, 5-31.

43. Preston, L.E. Analyzing corporate social performance: Methods and results. J. Contemp. Bus. 1978, 7, 135-150.

44. Brammer, S.; Millington, A. Does it pay to be different? An analysis of the relationship between corporate social and financial performance. Strateg. Manag. J. 2008, 29, 1325-1343.

45. McGuire, J.B.; Schneeweis, T.; Branch, B. Perceptions of firm quality: A cause or result of firm performance. J. Manag. 1990, 16, 167-180. 
46. Allouche, J.; Laroche, P. A meta-analytical investigation of the relationship between corporate social and financial performance. Revue de Gestion des Ressources Humaines 2005, 57, 18-41.

47. Seifert, B.; Morris, S.A.; Bartkus, B.R. Having, giving, and getting: Slack resources, corporate philanthropy, and firm financial performance. Bus. Soc. 2004, 43, 135-161.

48. Freeman, R.E. Strategic Management: A stakeholder Approach; Harpercollins College Div: New York, NY, USA, 1984.

49. Christmann, P. Effects of "Best Practices" of environmental management on cost advantage: The role of complementary assets. Acad. Manag. J. 2000, 43, 663-680.

50. Ruf, B.M.; Muralidhar, K.; Brown, R.M.; Janney, J.J.; Paul, K. An Empirical investigation of the relationship between change in corporate social performance and financial performance: A stakeholder theory perspective. J. Bus. Ethics 2001, 32, 143-156.

51. McGuire, J.B.; Sundgren, A.; Schneeweis, T. Corporate social responsibility and firm financial performance. Acad. Manag. J. 1988, 31, 854-872.

52. Choi, Y.; Yu, Y. The influence of perceived corporate sustainability practices on employees and organizational performance. Sustainability 2014, 6, 348-364.

53. Harrison, J.S.; John, C.H.S. Strategic Management of Organizations and Stakeholders; West Publishing Company: Minnesota, MN, USA, 1994.

54. Kotter, J.P.; Heskett, J.L. Corporate Culture and Performance; Free Press: New York, NY, USA, 1992.

55. Kapstein, E.B. The corporate ethics crusade. Foreign Aff. 2001, 80, 105-119.

56. Ribstein, L.E. Accountability and responsibility in corporate governance. Notre Dame Law Rev. 2005, 81, Article 5 .

57. Peloza, J. Using corporate social responsibility as insurance for financial performance. Calif. Manag. Rev. 2006, 48, 52-72.

58. Pan, X.; Sha, J.; Zhang, H.; Ke, W. Relationship between corporate social responsibility and financial performance in the mineral Industry: Evidence from Chinese mineral firms. Sustainability 2014, 6, 4077-4101.

59. Turban, D.B.; Greening, D.W. Corporate social performance and organizational attractiveness to prospective employees. Acad. Manag. J. 1997, 40, 658-672.

60. Hofstede, G. Culture's Consequences; Sage Publications: Thousand Oaks, CA, USA, 1980.

61. Schwartz, S.H. Cultural dimensions of values-Towards an understanding of national differences. In Individualism and Collectivism: Theoretical and Methodological Issues; Kim, U., Triandis, C., Kagitcibasi, C., Choi, S.C., Yoon, G., Eds.; Sage: Thousand Oaks, CA, USA; pp. 85-119.

62. Triandis, H.C. The self and social behavior in differing cultural contexts. Psychol. Rev. 1989, 96, 506-520.

63. Williams, C.A.; Aguilera, R.V. Corporate social responsibility in a comparative perspective. In The Oxford Handbook of Corporate Social Responsibility; Oxford University Press: New York, NY, USA, 2008; pp. 452-472.

64. Oreilly, C.A.; Chatman, J.A. Culture as social control: Corporations, cults, and commitment. Res. Organ. Behav. 1996, 18, 157-200.

65. Schein, E.H. Organizational Culture and Leadership; John Wiley \& Sons: San Francisco, CA, USA, 2010; Volume 2. 
66. Sirmon, D.G.; Lane, P.J. A model of cultural differences and international alliance performance. J. Int. Bus. Stud. 2004, 35, 306-319.

67. Welford, R. Corporate social responsibility in Europe, North America and Asia. J. Corp. Citizsh. 2005, 2005, 33-52.

68. Maignan, I.; Ralston, D.A. Corporate social responsibility in Europe and the US: Insights from businesses' self-presentations. J. Int. Bus. Stud. 2002, 33, 497-514.

69. Baughn, C.C.; Bodie, N.L.; McIntosh, J.C. Corporate social and environmental responsibility in Asian countries and other geographical regions. Corp. Soc. Responsib. Environ. Manag. 2007, 14, 189-205.

70. Aaronson, S.A. Corporate Responsibility in the global village: The British Role model and the American laggard. Bus. Soc. Rev. 2003, 108, 309-338.

71. Amann, B.; Caby, J.; Jaussaud, J.; Pineiro, J. Shareholder activism for corporate social responsibility: Law and practice in the United States, Japan, France and Spain. In The New Corporate Accountability-Corporate Social Responsibility and the Law; Cambridge University Press: Cambridge, UK, 2007.

72. Aoki, M. Information, Incentives and Bargaining in the Japanese Economy: A Microtheory of the Japanese Economy; Cambridge University Press: Cambridge, UK, 1989.

73. Lindenberg, E.B.; Ross, S.A. Tobin's q ratio and industrial organization. J. Bus. 1981, 54, 1-32.

74. Lee, D.E.; Tompkins, J.G. A modified version of the Lewellen and Badrinath measure of Tobin's q. Financ. Manag. 1999, 28, 20-31.

75. McWilliams, A.; Siegel, D. Corporate social responsibility and financial performance: Correlation or misspecification? Strateg. Manag. J. 2000, 21, 603-609.

76. Elsayed, K.; Paton, D. The impact of environmental performance on firm performance: Static and dynamic panel data evidence. Struct. Chang. Econ. Dyn. 2005, 16, 395-412.

(C) 2015 by the authors; licensee MDPI, Basel, Switzerland. This article is an open access article distributed under the terms and conditions of the Creative Commons Attribution license (http://creativecommons.org/licenses/by/4.0/). 